\title{
Optimization of $\mathbf{M}_{4}$ positive allosteric modulators (PAMs): The discovery of VU0476406, a non-human primate in vivo tool compound for translational pharmacology
}

\author{
Bruce J. Melancon ${ }^{a, b}$, Michael R. Wood ${ }^{a, c}$, Meredith J. Noetzel ${ }^{a, b}$, Kellie D. Nance ${ }^{a}$, Eileen \\ M. Engelberga ${ }^{a}$, Changho Han ${ }^{a}$, Atin Lamsal ${ }^{a}$, Sichen Chang ${ }^{a}$, Hyekyung P. Cho ${ }^{a, b}$, Frank W. \\ Byers $^{a}$, Michael Bubsera ${ }^{a}$, Carrie K. Jones ${ }^{a, b, e}$, Colleen M. Niswender ${ }^{a, b, e}$, Michael W. Wood ${ }^{d}$, \\ Darren W. Engers ${ }^{a, b}$, Dedong $\mathbf{W u}^{f}$, Nicholas J. Brandond, Mark E. Duggand, P. Jeffrey \\ Conn $^{a, b, e}$, Thomas M. Bridges ${ }^{a, b},{ }^{,}$, and Craig W. Lindsley ${ }^{a, b, c,{ }^{*}}$ \\ avanderbilt Center for Neuroscience Drug Discovery, Vanderbilt University Medical Center, \\ Nashville, TN 37232, USA \\ bepartment of Pharmacology, Vanderbilt University School of Medicine, Nashville, TN 37232, \\ USA \\ 'Department of Chemistry, Vanderbilt University, Nashville, TN 37232, USA \\ dAstraZeneca, Neuroscience, Innovative Medicines \& Early Development, Waltham, \\ Massachusetts 02451 USA \\ eVanderbilt Kennedy Center, Vanderbilt University School of Medicine, Nashville, TN 37232, USA \\ ${ }^{f}$ AstraZeneca, Pharmaceutical Science, 35 Gatehouse Drive, Waltham, MA 02451, USA
}

\begin{abstract}
This letter describes the further chemical optimization of the 5-amino-thieno[2,3-c]pyridazine series (VU0467154/VU0467485) of $\mathrm{M}_{4}$ positive allosteric modulators (PAMs), developed via iterative parallel synthesis, culminating in the discovery of the non-human primate (NHP) in vivo tool compound, VU0476406 (8p). VU0476406 is an important in vivo tool compound to enable translation of pharmacodynamics from rodent to NHP, and while data related to a Parkinson's disease model has been reported with 8p, this is the first disclosure of the optimization and discovery of VU0476406, as well as detailed pharmacology and DMPK properties.
\end{abstract}

\section{Graphical abstract}

To create your abstract, type over the instructions in the template box below. Fonts or abstract dimensions should not be changed or altered.9.0_/0

\footnotetext{
*To whom correspondence should be addressed: thomas.m.bridges@ vanderbilt.edu and craig.lindsley@ vanderbilt.edu. Publisher's Disclaimer: This is a PDF file of an unedited manuscript that has been accepted for publication. As a service to our customers we are providing this early version of the manuscript. The manuscript will undergo copyediting, typesetting, and review of the resulting proof before it is published in its final citable form. Please note that during the production process errors may be discovered which could affect the content, and all legal disclaimers that apply to the journal pertain.
} 


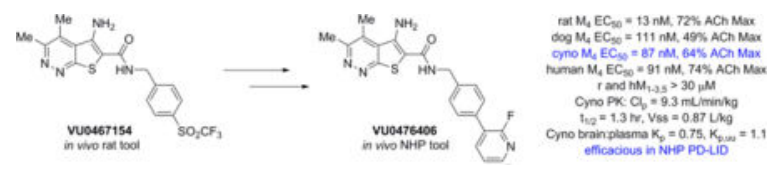

\section{Keywords}

$\mathrm{M}_{4}$; Muscarinic acetylcholine receptor; Positive allosteric modulator (PAM); Non-human primate (NHP); Structure-Activity Relationship (SAR)

Muscarinic acetylcholine receptor subtype $4\left(\mathrm{M}_{4}\right)$ positive allosteric modulators (PAMs) represent a fundamentally new approach to treat multiple symptom domains of schizophrenia, Huntington's disease and Parkinson's disease (PD). ${ }^{1-12} \mathrm{M}_{4}$ PAMs (Figure 1) represent the extreme of allosteric modulator caveats in terms of steep SAR, species differences in pharmacology (rat versus human versus cynomolgus (cyno) monkey versus $\operatorname{dog} \mathrm{M}_{4}$ PAM potency, affinity/cooperativity and subtype selectivity), poor solubility, and/or low CNS penetration. ${ }^{3,10-16}$ Work in this area has been challenging since the first report by Eli Lilly of $\mathbf{1}$, a human-preferring $\mathrm{M}_{4}$ PAM. ${ }^{1}$ Subsequent optimization efforts afforded $\mathbf{2}$, which provided the first in vivo proof-of-concept (POC) for selective $\mathrm{M}_{4}$ potentiation of endogenous acetylcholine in reversing amphetamine-induced hyperlocomotion (AHL) in rats. ${ }^{3}$ Further efforts improved physiochemical/DMPK properties and delivered the in vivo rodent POC tool compound, $3 .{ }^{11,15}$ Finally, $\mathbf{4}$ afforded a balance in $\mathrm{M}_{4}$ PAM activity across species, and was evaluated in depth as our first potential $\mathrm{M}_{4}$ PAM clinical candidate. ${ }^{16}$ Despite these advances, we required an in vivo non-human primate (NHP) POC tool compound for use in translational efficacy studies, primate PD models and biomarker studies that could be freely shared with collaborators. In this Letter, we detail the discovery effort that led to VU0467406, an in vivo $\mathrm{M}_{4}$ PAM non-human primate (NHP) tool compound.

As 4 offered balanced $\mathrm{M}_{4}$ PAM activity across species, we focused our efforts on this chemotype. ${ }^{16}$ A multitude of substituted benzyl amides had previously been explored, and SAR suggested a large lipophilic binding pocket accessible to the 4-position substituent, e.g., the 4- $\mathrm{SO}_{2} \mathrm{CF}_{3}$ moiety of $\mathbf{3}$ and related analogs. Interestingly, and despite their prevalence in GPCR ligands, we never synthesized and evaluated any biaryl or heterobiaryl methyl amide congeners; therefore, we focused our search for an NHP in vivo tool within this unexplored chemical space.

The synthesis of analogs 8 proved to be straightforward. Condensation of commercially available 3-chloro-5,6-dimethylpyridazine-4-carbonitrile 5 with methyl thioglycolate under basic conditions smoothly affords the sodium carboxylate $\mathbf{6}$ in $78 \%$ yield. A HATUmediated amide coupling with 2-, 3- or 4-bromobenzyl amines then delivers analogs 7 in yields ranging from 45-92\%. A subsequent Stille or Suzuki cross-coupling reaction with a diverse range of aryl and heteroaryl moieties delivers analogs $\mathbf{8}$ in yields ranging from 58$90 \% .^{17}$

SAR was driven using activity at the human $\mathrm{M}_{4}$ receptor (potency in functional assay), but key compounds were assessed on rat and cyno $\mathrm{M}_{4}$ as well, as the goal was an NHP tool 
compound. As shown in Table 1, many potent human $\mathrm{M}_{4}$ PAMs were discovered and several displayed attractive DMPK profiles and excellent CNS penetration (brain:plasma $\mathrm{K}_{\mathrm{p}}$ and $\mathrm{K}_{\mathrm{p}, \mathrm{uu}}$ ) vide infra. Initial evaluation of the 2-, 3- and 4-bromobenzyl derivatives, 7a-c respectively, demonstrated a clear preference for 3- and 4- substitution. Conversion of these into the corresponding biaryl analogs, 8a-c, confirmed the finding, with the 2-phenyl derivative 8a inactive $\left(\mathrm{hM}_{4} \mathrm{EC}_{50}>10 \mu \mathrm{M}\right)$, the 3-phenyl congener $\mathbf{8 b}$ weak $\left(\mathrm{hM}_{4} \mathrm{EC}_{50}=\right.$ $1.65 \mu \mathrm{M})$ while the 4-phenyl derivative 8c displayed good $\mathrm{M}_{4}$ PAM activity $\left(\mathrm{hM}_{4} \mathrm{EC}_{50}=\right.$ $319 \mathrm{nM})$. Thus, future efforts focused solely on 4-substituted biaryl and heterobiaryl analogs 8d-p. PAM 8c showed low efficacy and poor physiochemical properties and a high cLogP $(>4)$; therefore, we elected to evaluate diverse azaheterocycles in an attempt to improve physiochemical properties, enable salt formation and lower lipophilicity. Exploration of the pyridyl biaryl analogs $\mathbf{8 d - f}$ showed robust SAR. Potency increased as the pyridine nitrogen was moved from the 2-position $\left(\mathbf{8 d}, \mathrm{hM}_{4} \mathrm{EC}_{50}=232 \mathrm{nM}\right)$, to the 3-position $\left(\mathbf{8 e}, \mathrm{hM}_{4} \mathrm{EC}_{50}\right.$ $=103 \mathrm{nM})$ and finally to the 4-position $\left(\mathbf{8 f}, \mathrm{hM}_{4} \mathrm{EC}_{50}=36 \mathrm{nM}\right)$. Other heterocycles such as pyridazine $(\mathbf{8 g})$, pyrazine $(\mathbf{8 h})$, pyrimidine $(\mathbf{8 i}$ and $\mathbf{8 j}$ ) were also well tolerated. Attempts to modulate the pyridine basicity in $\mathbf{8 d - f}$ by the incorporation of fluorine atoms, as in $\mathbf{8 k - p}$, afforded a broad spectrum of activity, with $\mathbf{8 k}, \mathbf{8 m}$ and $\mathbf{8 p}$ displaying good $\mathrm{hM}_{4}$ PAM potency and efficacy. From these initial analogs, PAMs 8f, 8k, 8m and 8p were selected for more in-depth DMPK profiling.

As shown in Table 2, all four PAMs showed attractive cLogPs (2.66 to 2.92) and conserved TPSAs with molecular weights below 500. All were highly bound in plasma, except $\mathbf{8 f}$, which also showed low rat clearance in vivo (despite high in vitro predicted rat $\mathrm{CL}_{\mathrm{hep}}$, a likely consequence of excluding fuplasma/fu $\mathrm{u}_{\text {mic }}$ terms from the well-stirred equation used for prediction) and high rat CNS penetration (brain:plasma $K_{p}=0.94, K_{p, u u}=1.1$ ). However, 8f, as expected due to the naked pyridine ring, was a potent inhibitor of multiple $\mathrm{CYP}_{450} \mathrm{~s}\left(\mathrm{IC}_{50} \mathrm{~s}<10 \mu \mathrm{M}\right)$, including $3 \mathrm{~A} 4\left(\mathrm{IC}_{50}=340 \mathrm{nM}\right)$. Similarly, both $8 \mathbf{k}$ and $\mathbf{8 m}$ were potent inhibitors of $1 \mathrm{~A} 2$ ( $\mathrm{IC}_{50} \mathrm{~s}$ of $2.5 \mu \mathrm{M}$ and $790 \mathrm{nM}$, respectively) with low rat in vivo clearance $\left(\mathrm{CL}_{\mathrm{p}} \mathrm{s}\right.$ of 3.6 and $1.7 \mathrm{~mL} / \mathrm{min} / \mathrm{kg}$, respectively) and moderate total brain distribution $\left(\mathrm{K}_{\mathrm{p}} \mathrm{s}<0.21\right)$. Here, 8p stood out, with an improved CYP inhibition profile (all $\left.\mathrm{IC}_{50} \mathrm{~s} \geq 11 \mu \mathrm{M}\right)$ andfavorable rat $\mathrm{PK}\left(\mathrm{CL}_{\mathrm{p}}=1.6 \mathrm{~mL} / \mathrm{min} / \mathrm{kg}\right.$, elim. $\left.\mathrm{t}_{1 / 2}=2.7 \mathrm{hr}\right)$ despite a moderate $\mathrm{K}_{\mathrm{p}}(0.11)$, an attractive $\mathrm{K}_{\mathrm{p} \text {,uu }}(1.2)$. Moreover, 8p was not a human P-gp substrate in vitro $(\mathrm{ER}=1.7)$. However, we noted a lack of an in vitro/in vivo correlation (IVIVC) between the in vitro predicted $\mathrm{CL}_{\mathrm{hep}}$ and the in vivo $\mathrm{CL}_{\mathrm{p}}$. Employing a revised prediction method (inclusion of binding terms in the well-stirred model), the predicted rat $\mathrm{CL}_{\mathrm{hep}}$ decreased to $0.49 \mathrm{~mL} / \mathrm{min} / \mathrm{kg}$, and a more robust IVIVC resulted.

While 8p emerged as the most attractive of the analogs of $\mathbf{8}$ that were surveyed, we wanted to explore modifications to the benzylic phenyl ring before initiating a more exhaustive profiling effort around 8p. While many analogs in which fluorine atoms and/or nitrogen atoms were added retained excellent $\mathrm{M}_{4}$ PAM potency $\left(\mathrm{EC}_{50} \mathrm{~s}<200 \mathrm{nM}\right)$, all suffered from increased cLogP, poor in vitro/ in vivo clearance and/or unacceptable CYP inhibition profiles. Thus, $\mathbf{8 p}$ was advanced as a potential NHP tool compound. 
Next, 8p was evaluated as an $\mathrm{M}_{4}$ PAM across multiple species (Figure 2). Unlike all predecessors (except 4 ), 8p was a potent $\mathrm{M}_{4} \mathrm{PAM}$ at the rat $\left(\mathrm{rM}_{4} \mathrm{EC}_{50}=13.5 \mathrm{nM}, \mathrm{pEC}_{50}=\right.$ $7.93 \pm 0.17,72 \pm 4 \%$ ACh Max $)$, human $\left(\mathrm{hM}_{4} \mathrm{EC}_{50}=91.0 \mathrm{nM}, \mathrm{pEC}_{50}=7.04 \pm 0.11,74 \pm 3 \%\right.$ ACh Max $), \operatorname{dog}\left(\mathrm{dM} 4 \mathrm{EC}_{50}=111 \mathrm{nM}, \mathrm{pEC}_{50}=6.95 \pm 0.12,49 \pm 4 \%\right.$ ACh Max $)$ and cyno receptors $\left(\mathrm{cM}_{4} \mathrm{EC}_{50}=87.3 \mathrm{nM}, \mathrm{pEC}_{50}=7.06 \pm 0.25,64 \pm 2 \% \mathrm{ACh} \mathrm{Max}\right)$. ACh concentration response curve (CRC) fold-shift $\mathrm{Ca}^{2+}$ mobilization and $\mathrm{ACh}$ competition binding (with $\left[{ }^{3} \mathrm{H}\right.$ $N$-methylscopolamine) assays provided operational model parameters for $\mathbf{8 p}$ at $\mathrm{rM}_{4}\left(K_{B}=\right.$ $0.37 \mu \mathrm{M}, \mathrm{a}=8.4, \beta=9.1), \mathrm{hM}_{4}\left(K_{B}=2.8 \mu \mathrm{M}, \mathrm{a}=7.0, \beta=21\right)$, and cyno $\mathrm{M}_{4}\left(K_{B}=2.1 \mu \mathrm{M}\right.$, $a=28.2, \beta=2.5$ ); all experiments are $n=3-4$, performed in duplicate. Moreover, $8 \mathbf{p}$ was inactive $\left(\mathrm{EC}_{50}>30 \mu \mathrm{M}\right)$ at both rat and human $\mathrm{M} 1-3,5$ (and also inactive at dog and cyno $\mathbf{M}_{2}$, data not shown). These data were highly noteworthy and indicated that $\mathbf{8 p}$ was a potent and highly-selective NHP $\mathrm{M}_{4}$ PAM. A broad secondary pharmacology panel (Cerep) revealed only one sub-micromolar off-target activity for $\mathbf{8 p}-$ a rat $\mathrm{GABA}_{\mathrm{A}}$ receptor (benzodiazepine site) binding $\mathrm{IC}_{50}=0.44 \mu \mathrm{M}$, which was subsequently de-risked by a functional assay determination (no activity at $10 \mu \mathrm{M}$ ). A functional electrophysiology hERG assay with $8 p$ was likewise clean $\left(\mathrm{IC}_{50}>33 \mu \mathrm{M}\right)$, and a mini-Ames assay (TA98 and TA100 strains \pm S9) was negative for mutagenicity. In addition, $\mathbf{8 p}$ was devoid of evidence for CYP 1A2/2B6/3A4 induction potential in cryopreserved human hepatocytes (48 hr incubation with enzyme activity readout; $\mathrm{EC}_{50} \mathrm{~s}>50 \mu \mathrm{M}, \mathrm{E}_{\max } \mathrm{s}<2$ ), and in a 4 day sub-chronic dosing rat study $(10 \mathrm{mg} / \mathrm{kg}$, QD PO, $n=2)$, the day 4 versus day $1 \mathrm{AUC}_{0-\infty}$ ratio was 0.77 , indicating little to no auto-induction in vivo in rat.

Compound $\mathbf{8 p}$ was found to possess a largely attractive PK profile across species. In rat, 8p as a $10 \mathrm{mg} / \mathrm{kg}$ solution dose achieved good oral bioavailability $(61 \% \mathrm{~F})$, and the $\mathrm{HCl}$ salt of 8p, when dosed as a suspension, achieved $54 \%$ F. PAM 8p likewise exhibited favorable IV and PO PK in $\operatorname{dog}\left(\mathrm{CL}_{\mathrm{p}}=5.5 \mathrm{~mL} / \mathrm{min} / \mathrm{kg}\right.$, elim. $\mathrm{t}_{1 / 2}=1.0$ hour, $\mathrm{V}_{\mathrm{ss}}=0.70 \mathrm{~L} / \mathrm{kg}$, and $47 \% \mathrm{~F}$ from $3 \mathrm{mg} / \mathrm{kg}$ suspension dose of the $\mathrm{HCl}$ salt) and favorable IV PK in cynomolgus monkey $\left(\mathrm{CL}_{\mathrm{p}}=9.3 \mathrm{~mL} / \mathrm{min} / \mathrm{kg}\right.$, elim. $\mathrm{t}_{1 / 2}=1.3$ hours, $\left.\mathrm{V}_{\mathrm{ss}}=0.87 \mathrm{~L} / \mathrm{kg}\right)$, but with low oral bioavailability $(4.7 \% \mathrm{~F}$ from $10 \mathrm{mg} / \mathrm{kg}$ solution dose of $\mathrm{HCl}$ salt). CNS penetration of $\mathbf{8 p}$ was also assessed in dog (brain:plasma $\mathrm{K}_{\mathrm{p}}=0.74, \mathrm{~K}_{\mathrm{p}, \mathrm{uu}}=2.6, \mathrm{C}_{\mathrm{csf}}: \mathrm{C}_{\text {plasma,u }}=4.8$ at $2.0 \mathrm{hr}$; via a terminal study) and NHP (brain:plasma $\mathrm{K}_{\mathrm{p}}=0.75, \mathrm{~K}_{\mathrm{p}, \mathrm{uu}}=1.1, \mathrm{C}_{\mathrm{csf}}: \mathrm{C}_{\text {plasma,u }}=1.0$ at 1 hr; via a PET study measuring brain distribution of $\left[{ }^{18} \mathrm{~F}\right]-\mathrm{VU} 0476406$ after IV administration), ${ }^{18}$ providing strong support for the utility of $\mathbf{8 p}$ in NHP behavioral models and biomarker studies.

Encouraged, we performed additional studies to evaluate 8p (VU0476406) as a potential candidate for clinical development before releasing it as a public $\mathrm{M}_{4}$ PAM NHP tool compound. In vitro metabolite identification experiments employing cryopreserved hepatocytes found low turnover and no evidence for human unique metabolites, with rat and cyno anticipated to provide adequate coverage of human metabolites (Figure 3). Human $\mathrm{CYP}_{450}$ phenotyping experiments revealed that multiple CYPs (3A4 (predominant), 2D6, 2C19, 2C9 and 1A2) contribute to 8p's metabolism. Moreover, no significant levels of GSH conjugates were observed in reactive metabolism/bioactivation experiments with human hepatic microsomes, which further bolstered the potential to advance $\mathbf{8 p}$. 
Human PK prediction, utilizing multiple approaches, suggested that $\mathbf{8 p}$ would exhibit low clearance in man $\left(\mathrm{CL}_{\mathrm{p}}\right.$ between 1.3 to $\left.3.6 \mathrm{~mL} / \mathrm{min} / \mathrm{kg}\right)$ with a $6-17$ hour half-life. ${ }^{19}$ However, for projected 12-hour daily coverage (targeting an efficacious $\mathrm{C}_{\min }$ scaled from rat in vivo pharmacodynamic studies; data not shown), $\mathbf{8 p}$ was projected to require moderate to high BID oral doses (370-850 mg) due in large part to moderate predicted human oral F. In parallel, pharmaceutical science work on both the free base and $\mathrm{HCl}$ salt was performed, which found $8 \mathbf{p}$ to be highly crystalline with low aqueous solubility $(<0.5 \mu \mathrm{M}$ for free base at $\mathrm{pH}$ 7.4) and without a clean melt (free base decomposes at $243-246^{\circ} \mathrm{C}$ ), suggesting potential challenges to achieving requisite margins in nonclinical safety and toxicology studies. An X-ray crystal structure proved telling (Figure 4), highlighting a network of intraand inter-molecular hydrogen bonds forming a tight, helix-like packing with highly ordered $\pi$-stacking. Efforts to disrupt this network to enable acceptable solubility/dissolution with vehicles suitable for IND-enabling safety and toxicology studies were not successful. Thus, based on the suboptimal physiochemical properties of $\mathbf{8 p}$ and the high projected human doses, the program team decided to release $\mathbf{8 p}$ as a publicly available NHP $\mathrm{M}_{4}$ PAM tool compound.

Upon release, Surmeier and co-workers evaluated 8p (VU0476406) in both mouse and NHP models of L-DOPA-induced dyskinesia (LID), and found that administration of the $\mathrm{M}_{4}$ PAM ameliorates deficits in synaptic plasticity and behavior in PD-LID mice and NHPs. ${ }^{20}$ Specifically, 8p dosed at $10 \mathrm{mg} / \mathrm{kg}$ IV (route chosen due to low cyno oral F, vide supra) significantly reduced dyskinesia scores and involuntary movements in NHPs, thus providing early proof-of-concept for $\mathrm{M}_{4}$ PAMs in the management of Parkinson's disease and highlighting the utility of the compound 8p (VU0476406) in NHP studies.

In summary, we have detailed the discovery and characterization of the first reported $\mathrm{M}_{4}$ PAM non-human primate in vivo tool compound 8p (VU0476406), with similar $\mathrm{M}_{4}$ PAM activity across species. The studies presented here produced a required in vivo NHP POC tool compound for use in translational efficacy studies, primate PD models and biomarker studies that could be freely shared with collaborators. Initial results demonstrated that $\mathbf{8 p}$ significantly reduces dyskinesia scores and involuntary movements in NHPs, and provided early POC for $\mathrm{M}_{4}$ PAMs in the management of PD-LID. Further optimization efforts en route to $\mathrm{M}_{4}$ PAM clinical candidates for the treatment of schizophrenia and other disorders will be reported in due course.

\section{X-ray crystallographic data}

The X-ray crystal structure data for $\mathbf{8 p}$ was submitted to the Cambridge Crystallographic Data Centre (http://www.ccdc.cam.ac.uk) and assigned CCDC 1538487.

\section{Acknowledgments}

We thank the NIH for funding via the NIH Roadmap Initiative 1X01 MH077607 (C.M.N.), the Molecular Libraries Probe Center Network (U54MH084659 to C.W.L.), R01MH073676 (PJC) and U01MH087965 (Vanderbilt NCDDG). We also thank William K. Warren, Jr. and the William K. Warren Foundation who funded the William K. Warren, Jr. Chair in Medicine (to C.W.L.). We also thank key CROs that performed key higher species PK (Frontage), pharmaceutical science/X-ray work (Crystal Pharmatech) and Pgp assays (Absorption Systems). 


\section{References}

1. Chan WY, McKinize DL, Bose S, Mitchell SN, Witkins JM, Thompson RC, Christopoulos A, Birdsall NJ, Bymaster FP, Felder CC. Proc Natl Acad Sci USA. 2008; 105:10978-10983. [PubMed: 18678919]

2. Leach K, Loiancono RE, Felder CC, McKinize DL, Mogg A, Shaw DB, Sexton PM, Christopoulos A. Neuropsychopharmacology. 2010; 35:855-869. [PubMed: 19940843]

3. Brady A, Jones CK, Bridges TM, Kennedy PJ, Thompson AD, Breininger ML, Gentry PR, Yin H, Jadhav SB, Shirey J, Conn PJ, Lindsley CW. J Pharm \& Exp Ther. 2008; 327:941-953.

4. Pancani T, Foster DJ, Bichell T, Bradley E, Bridges TM, Klar R, Daniels JS, Jones CK, Bowman AB, Lindsley CW, Xiang Z, Conn PJ. Proc Natl Acad Sci USA. 2015; 112:14078-14083. [PubMed: 26508634]

5. Foster DJ, Wilson JM, Remke DH, Mahmood MS, Uddin MJ, Wess J, Patel S, Marnett LJ, Niswender CM, Jones CK, Xiang Z, Lindsley CW, Rook JM, Conn PJ. Neuron. 2016; 91:12241252.

6. Byun NE, Grannan M, Bubser M, Barry RL, Thompson A, Rosanelli J, Gowrishnakar R, Kelm ND, Damon S, Bridges TM, Melancon BJ, Tarr JC, Brogan JT, Avison MJ, Deutch AY, Wess J, Wood MR, Lindsley CW, Gore JC, Conn PJ, Jones CK. Neuropsychopharmacology. 2014; 39:1578-1593. [PubMed: 24442096]

7. Farrell M, Roth BL. Neuropsychopharmacology. 2010; 35:851-852. [PubMed: 20145632]

8. Jones CK, Byun N, Bubser M. Neuropsychopharmacology. 2012; 37:16-42. [PubMed: 21956443]

9. Shirey JK, Xiang Z, Orton D, Brady AE, Johnson KA, Williams R, Ayala JE, Rodriguez AL, Wess J, Weaver D, Niswender CM, Conn PJ. Nat Chem Bio. 2008; 4:42-50. [PubMed: 18059262]

10. Le U, Melancon BJ, Bridges TM, Utley TJ, Lamsal A, Vinson PN, Sheffler DJ, Jones CK, Morrison R, Wood MR, Daniels JS, Conn PJ, Niswender CM, Lindsley CW, Hopkins CR. Bioorg Med Chem Lett. 2013; 23:346-350. [PubMed: 23177787]

11. Kennedy JP, Bridges TM, Gentry PR, Brogan JT, Brady AE, Shirey JK, Jones CK, Conn PJ, Lindsley CW. ChemMedChem. 2009; 4:1600-1607. [PubMed: 19705385]

12. Salovich JM, Sheffler DJ, Vinson PN, Lamsal A, Utley TJ, Blobaum AL, Bridges TM, Le U, Jones CK, Wood MR, Daniels JS, Conn PJ, Niswender CM, Lindsley CW, Hopkins CR. Bioorg Med Chem Lett. 2012; 22:5084-5088. [PubMed: 22738637]

11. Bubser M, Bridges TM, Thorbeck DD, Gould RW, Grannan M, Noetzel MJ, Niswender CM, Daniels JS, Melancon BJ, Tarr JC, Wess J, Duggan ME, Brandon NJ, Dunlop J, Wood MW, Wood MR, Lindsley CW, Conn PJ, Jones CK. ACS Chem Neurosci. 2014; 5:920-942. [PubMed: 25137629]

12. Smith E, Chase P, Niswender CM, Conn PJ, Lindsley CW, Madoux F, Acosta M, Scampavia L, Spicer T, Hodder P. J Biomol Screening. 2015; 20:858-868.

13. Wood MR, Noetzel MJ, Tarr JC, Rodriguez AL, Lamsal A, Chang S, Foster JJ, Smith E, Hodder PS, Engers DW, Niswender CM, Brandon NJ, Wood MW, Duggan ME, Conn PJ, Bridges TM, Lindsley CW. Bioorg Med Chem Lett. 2016; 26:4282-4286. [PubMed: 27476142]

14. Wood MR, Noetzel MJ, Engers JL, Bollinger KA, Melancon BJ, Tarr JC, Han C, West M, Gregro AR, Lamsal A, Chang S, Ajmera S, Smith E, Chase P, Hodder PS, Bubser M, Jones CK, Hopkins CR, Emmitte KA, Niswender CM, Wood MW, Duggan ME, Conn PJ, Bridges TM, Lindsley CW. Bioorg Med Chem Lett. 2016; 26:3029-3033. [PubMed: 27185330]

15. Wood MR, Noetzel MJ, Poslunsey MS, Melancon BJ, Tarr JC, Lamsal A, Chang S, Luscombe VB, Weiner RL, Cho HP, Bubser M, Jones CK, Niswender CM, Wood MW, Brandon NJ, Engers DW, Duggan ME, Conn PJ, Bridges TM, Lindsley CW. Bioorg Med Chem Lett. 2017; 27:171-175. [PubMed: 27939174]

16. Wood MR, Noetzel MJ, Melancon BJ, Nance KD, Poslunsey MS, Hurtado MA, Luscombe VB, Weiner RL, Rodriguez AL, Lamsal A, Chang S, Bubser M, Blobaum AL, Engers DW, Niswender CM, Jones CK, Brandon NJ, Wood MW, Duggan ME, Conn PJ, Bridges TM, Lindsley CW. ACS Med Chem Lett. 2017; 8:233-238. [PubMed: 28197318]

17. Experimental for the synthesis of $\mathbf{8 p}$ (VU0476406), 5-amino- $N$-(4-(2-fluoropyridine-3yl)benzyl)-3,4-dimethylthieno[2,3-c] pyridazine-6-carboxamide. To a $5 \mathrm{~mL}$ microwave vial 
equipped with a stir bar was added 5-amino- $N$-(4-bromobenzyl)-3-dimethylthieno[2,3c]pyridazine6-carboxamide (50 mg, $0.13 \mathrm{mmol}$ ), (2-fluoropyridin-3-yl)boronic acid (36 $\mathrm{mg}, 0.26$ $\mathrm{mmol}), 10 \mathrm{~mol} \% \mathrm{Pd}(\mathrm{dppf}) \mathrm{Cl}_{2} \cdot \mathrm{CH}_{2} \mathrm{Cl}_{2}(10.3 \mathrm{mg}, 0.013 \mathrm{mmol})$. The microwave vial was sealed, evacuated and back-filled three times with argon. Then, an aqueous solution of potassium phosphate $\left(380 \mu \mathrm{L}, 1 \mathrm{M} \mathrm{K}_{3} \mathrm{PO}_{4}\right.$ in $\left.\mathrm{H}_{2} \mathrm{O}, 0.38 \mathrm{mmol}\right)$ was added, followed by THF $(1.3 \mathrm{~mL})$. The biphasic mixture was heated at $160{ }^{\circ} \mathrm{C}$ for $20 \mathrm{~min}$, and after cooling, the suspension was diluted with DCM and filtered through celite. Silica gel chromatography afforded $\mathbf{8 p}$ as an orange solid (40 mg, 80\%). LCMS: $\mathrm{R}_{\mathrm{T}}=0.623 \mathrm{~min},>99 \% @ 254 \mathrm{~nm},>99 \% @ 215 \mathrm{~nm} ; \mathrm{m} / \mathrm{z}(\mathrm{M}+1)=408 .{ }^{1} \mathrm{H}$ NMR (400 MHz, $\mathrm{CDCl}_{3}$, d (ppm)): 8.7 (t, J=4.0 Hz, 1H), 8.2 (d, J=4.0 Hz, 1H), 8.1-8.0 (m, 1H), $7.6(\mathrm{~d}, \mathrm{~J}=8.0 \mathrm{~Hz}, 2 \mathrm{H}), 7.5-7.4(\mathrm{~m}, 3 \mathrm{H}), 6.9(\mathrm{bs}, 2 \mathrm{H}), 4.5(\mathrm{~d}, \mathrm{~J}=4.0 \mathrm{~Hz}, 2 \mathrm{H}), 2.71(\mathrm{~s}, 3 \mathrm{H}), 2.70$ (s, $3 \mathrm{H})$. HRMS calc'd for $\mathrm{C}_{21} \mathrm{H}_{19} \mathrm{FN}_{5} \mathrm{OS}(\mathrm{M}+\mathrm{H}), 408.1294$; found 408.1298 .

18. Whole and regional brain distribution of total and calculated unbound VU0476406 was determined in NHP (cynomolgus monkey, $n=1$ ) via a PET study employing a single IV administration of $\left[{ }^{18} \mathrm{~F}\right]-\mathrm{VU} 0476406(145 \mathrm{MBq})$ and an approximate 2 hour data acquisition time postadministration; manuscript in preparation.

19. Prediction of human $\mathrm{CL}_{\mathrm{p}}$ was performed using two approaches: 1) the mean hepatic extraction ratio $\left(\mathrm{ER}_{\text {hep }}\right)$ observed in rat, dog, and $\mathrm{NHP}(0.17)$ applied to human $\left.\mathrm{Q}_{\mathrm{hep}} ; 2\right)$ in vitro to in vivo extrapolation of $\mathrm{CL}_{\mathrm{int}}$ (human hepatic microsomes) using the well-stirred model of organ

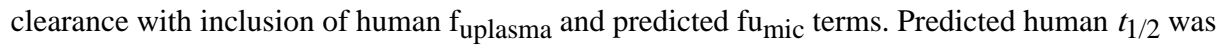
obtained from predicted $\mathrm{CL}_{\mathrm{p}}$ and a predicted $\mathrm{V}_{\mathrm{ss}}(1.9 \mathrm{~L} / \mathrm{kg})$ scaled allometrically from the observed rat and $\operatorname{dog} \mathrm{V}_{\mathrm{Ss}}$ with correction for species differences in fu plasma.

20. Shen W, Plotkin JL, Francardo V, Ko WKD, Xie Z, Li Q, Fieblinger T, Wess J, Neubig RR, Lindsley CW, Conn PJ, Greengrad P, Bezard E, Cenci MA, Surmeier DJ. Neuron. 2015; 88:762_ 773. [PubMed: 26590347] 


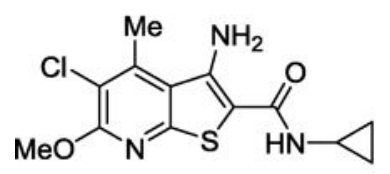

1, LY2033298

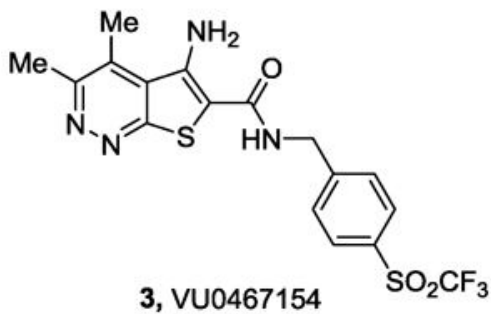

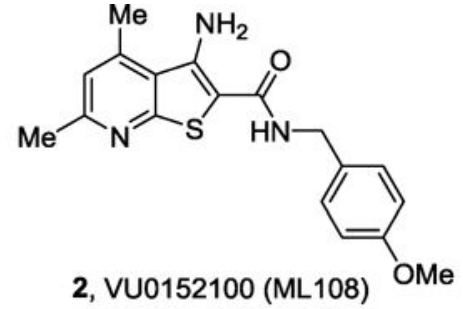

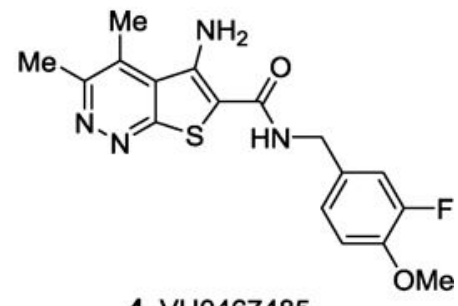

(AZ13713945)

Figure 1.

Structures of representative $\mathrm{M}_{4}$ PAMs 1-4, exemplifying an optimized rodent in vivo tool $\mathrm{M}_{4}$ PAM, VU0467154 (3) and the clinical candidate VU0467485/AZ13713945 (4). 


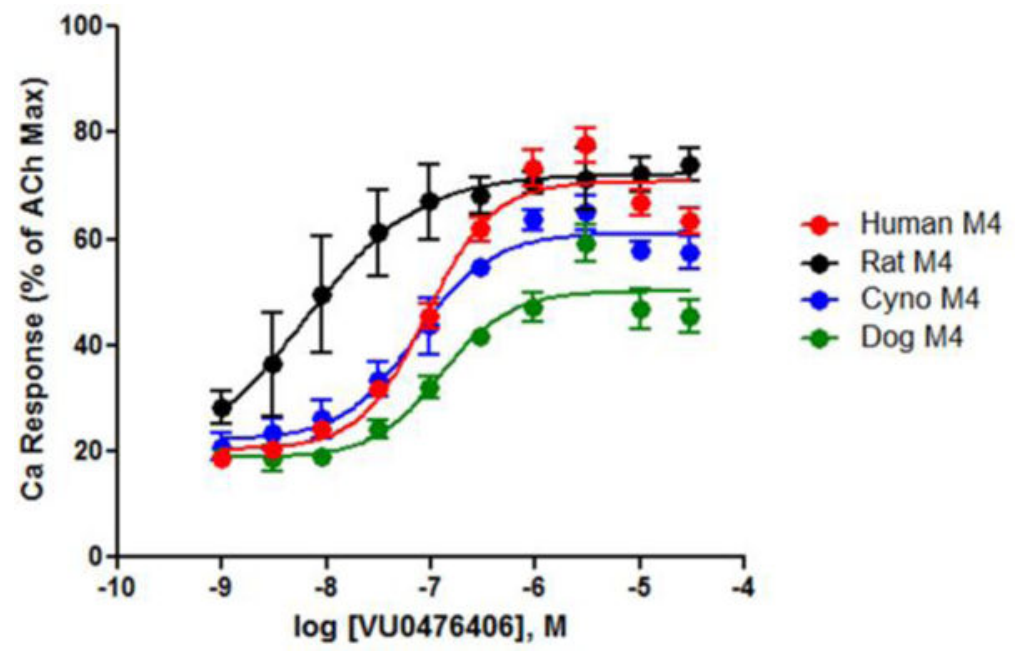

Figure 2.

$\mathrm{M}_{4}$ PAM concentration response curves (CRCs) for $\mathbf{8 p}$ (VU0476406) at human $\left(\mathrm{hM}_{4} \mathrm{EC}_{50}\right.$ $=91.0 \mathrm{nM}, \mathrm{pEC}_{50}=7.04 \pm 0.11,74 \pm 3 \%$ ACh Max $)$, rat $\left(\mathrm{rM}_{4} \mathrm{EC}_{50}=13.5 \mathrm{nM}, \mathrm{pEC}_{50}=\right.$ $7.93 \pm 0.17,72 \pm 4 \%$ ACh Max), cyno $\left(\mathrm{cM}_{4} \mathrm{EC}_{50}=87.3 \mathrm{nM}, \mathrm{pEC}_{50}=7.06 \pm 0.25,64 \pm 2 \%\right.$ $\mathrm{ACh}$ Max $)$ and $\operatorname{dog}\left(\mathrm{dM}_{4} \mathrm{EC}_{50}=111 \mathrm{nM}, \mathrm{pEC}_{50}=6.95 \pm 0.12,49 \pm 4 \%\right.$ ACh Max $)$. 

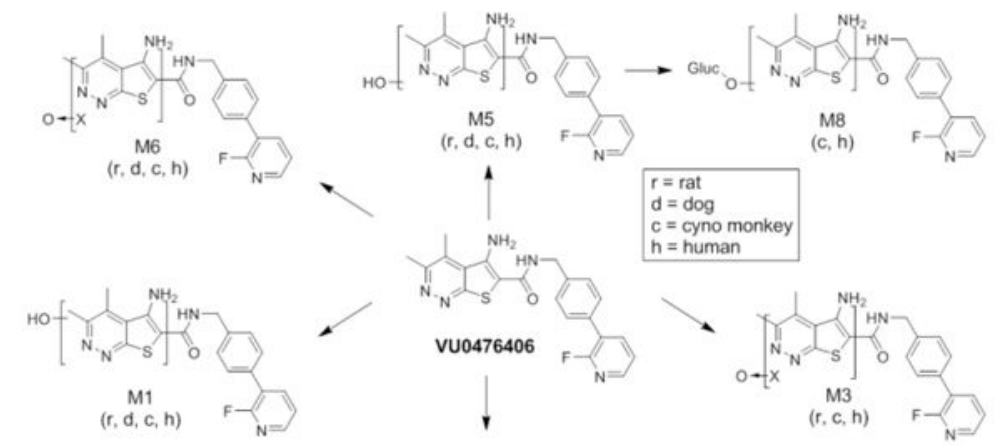

$\mathrm{h}=$ human
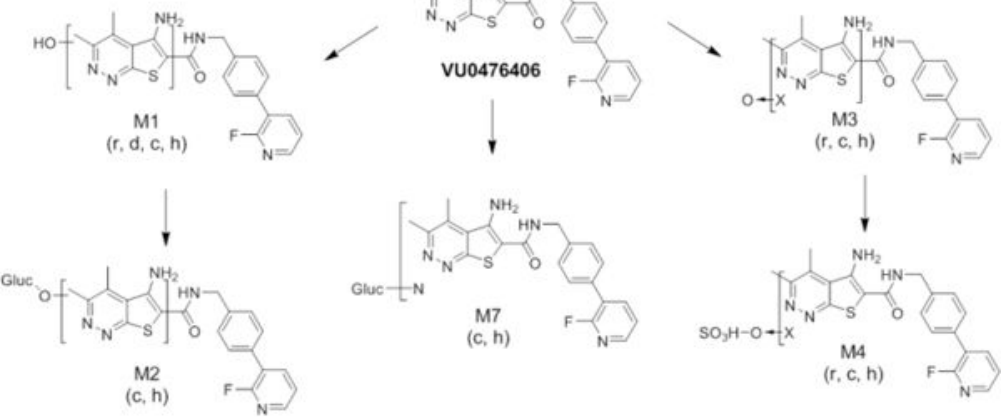

Figure 3.

In vitro biotransformation of $\mathbf{8 p}$ (VU0476406) in cryopreserved hepatocytes from multiple species (rat, dog, cynomolgus monkey, and human).

Bioorg Med Chem Lett. Author manuscript; available in PMC 2018 June 01. 

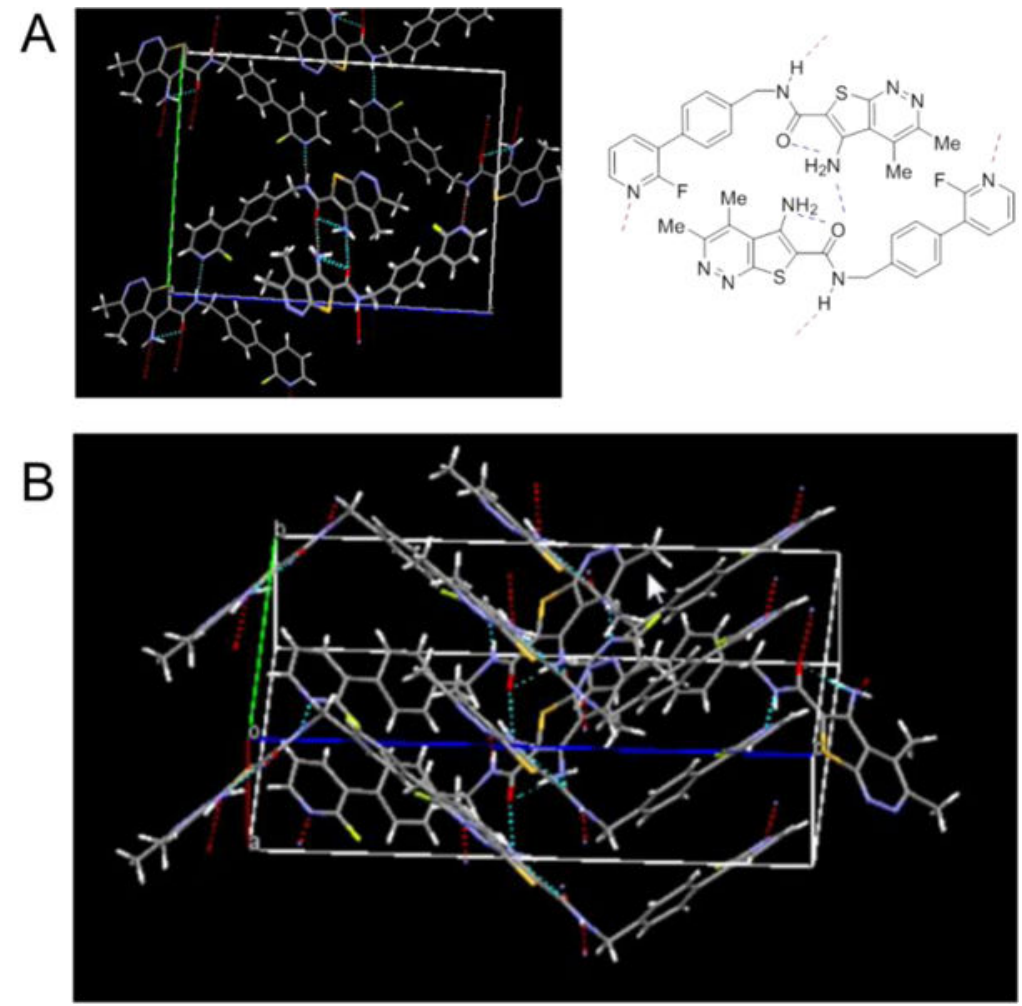

Figure 4.

X-ray crystal structure (CCDC 1538487) of 8p. A) Clear intra- and intermolecular hydrogen bonds are present (H-bond between pyridine and amide is linear, $\mathrm{H}$-bond network forms a helix). B) All aryl/heteroaryl rings are oriented to allow $\pi$-stacking on both faces. Unit cell dimensions: $22.3 \times 16.8 \times 5.04 \AA$. Combined, this crystalline lattice explains the compound's poor aqueous solubility. 

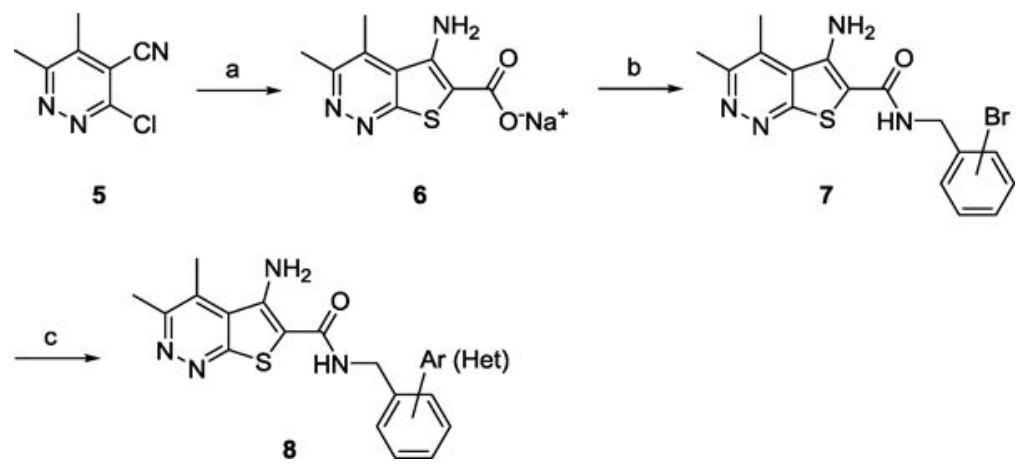

Scheme 1. Synthesis of $\mathrm{M}_{\mathbf{4}}$ PAM analogs $8 .^{\mathrm{a}}$

${ }^{a}$ Reagents and conditions: (a) Methyl thioglycolate, $\mathrm{MeOH}, 1 \mathrm{M}$ aq. $\mathrm{NaOH}, 150{ }^{\circ} \mathrm{C}$, microwave, 30 min, 78\%; (b) bromobenzyl amine, HATU, DMF, DIPEA, 2 h, 45-92\%; (c) 5 $\mathrm{mol} \% \mathrm{Pd}(\mathrm{dppf}) \mathrm{Cl}_{2} \cdot \mathrm{CH}_{2} \mathrm{Cl}_{2}, \mathrm{Bu}_{3} \mathrm{SnAr}(\mathrm{Het}), \mathrm{THF}, 65-80 \%$ or $5 \mathrm{~mol} \% \mathrm{Pd}(\mathrm{dppf}) \mathrm{Cl}_{2} \cdot \mathrm{CH}_{2} \mathrm{Cl}_{2}$, $(\mathrm{HO})_{2} \mathrm{BAr}(\mathrm{Het}), \mathrm{K}_{3} \mathrm{PO}_{4}, \mathrm{THF} / \mathrm{H}_{2} \mathrm{O}, 100{ }^{\circ} \mathrm{C}, 58-90 \%$. 
Table 1

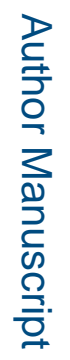

Structures and activities for human $\mathrm{M}_{4}$ PAM analogs 7 and 8 .

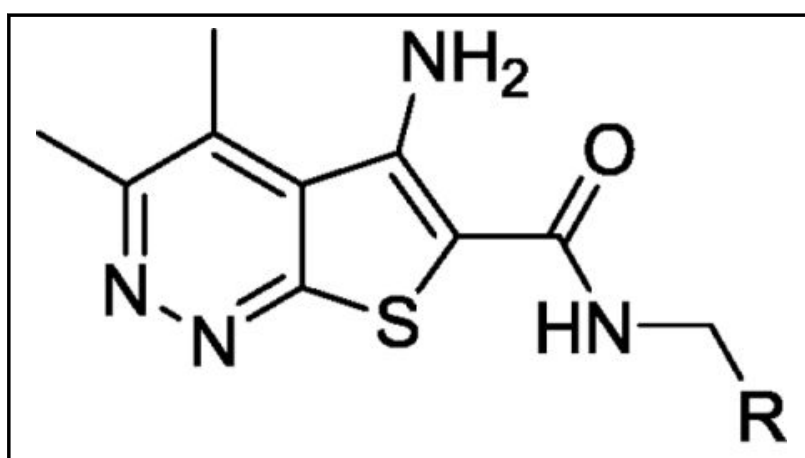

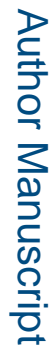

\begin{tabular}{|c|c|c|c|}
\hline Cpd & $\mathbf{R}$ & $\begin{array}{c}\mathbf{h M}_{4} \\
\mathbf{E C}_{50}(\mathbf{n M})^{a} \\
{[\% \mathrm{ACh} \mathrm{Max} \pm \mathrm{SEM}]}\end{array}$ & $\begin{array}{c}\mathbf{h M}_{4} \\
\mathbf{p E C}_{50} \\
( \pm \mathrm{SEM})\end{array}$ \\
\hline $7 a$ & & $\begin{array}{c}>10,000 \\
{[31 \pm 2]}\end{array}$ & $>5$ \\
\hline $7 \mathrm{~b}$ & & $\begin{array}{c}185 \\
{[84 \pm 2]}\end{array}$ & $6.77 \pm 0.13$ \\
\hline $7 \mathrm{c}$ & & $\begin{array}{c}187 \\
{[82 \pm 2]}\end{array}$ & $6.74 \pm 0.07$ \\
\hline $8 a$ & & $\begin{array}{c}>10,000 \\
{[30 \pm 1]}\end{array}$ & $>5$ \\
\hline $8 b$ & & $\begin{array}{c}1,650 \\
{[41 \pm 3]}\end{array}$ & $5.80 \pm 0.12$ \\
\hline $8 \mathrm{cc}$ & & $\begin{array}{c}319 \\
{[49 \pm 6]}\end{array}$ & $6.53 \pm 0.12$ \\
\hline $8 \mathrm{~d}$ & & $\begin{array}{c}232 \\
{[75 \pm 5]}\end{array}$ & $6.67 \pm 0.12$ \\
\hline $8 \mathrm{e}$ & & $\begin{array}{c}103 \\
{[63 \pm 4]}\end{array}$ & $7.20 \pm 0.31$ \\
\hline $8 \mathrm{f}$ & & $\begin{array}{c}36 \\
{[83 \pm 8]}\end{array}$ & $7.57 \pm 0.19$ \\
\hline
\end{tabular}

Bioorg Med Chem Lett. Author manuscript; available in PMC 2018 June 01. 


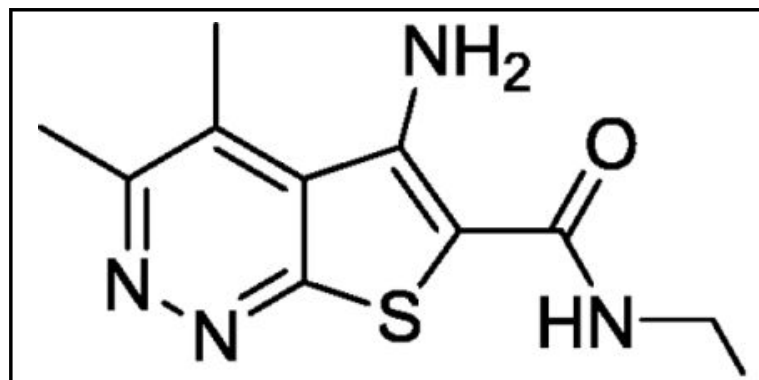

$\mathbf{R}$

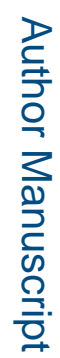

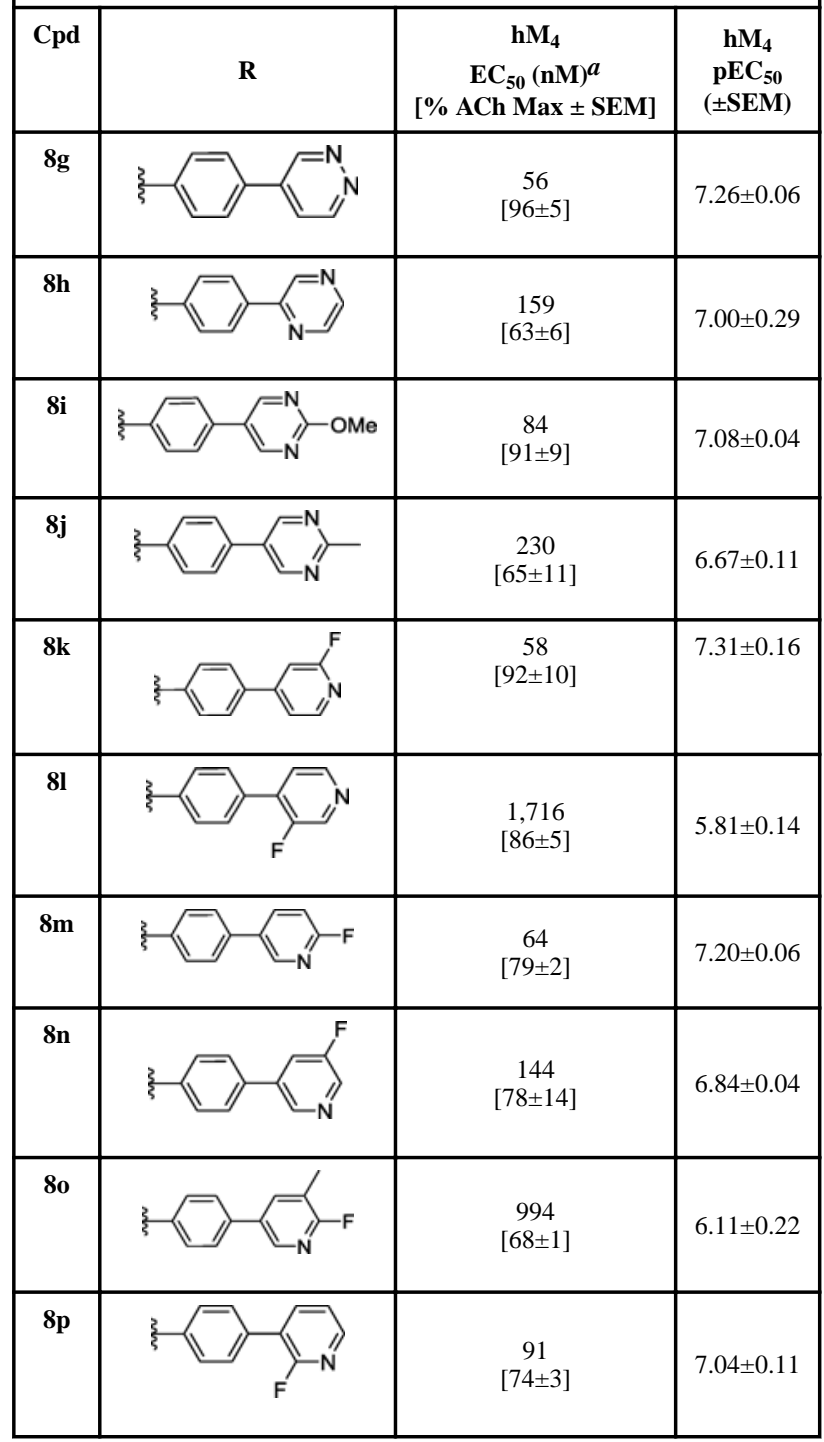

Bioorg Med Chem Lett. Author manuscript; available in PMC 2018 June 01. 
${ }^{a}$ Calcium mobilization assays with $\mathrm{hM}_{4} / \mathrm{Gqi5}-\mathrm{CHO}$ cells performed in the presence of an $\mathrm{EC}_{20}$ fixed concentration of acetylcholine; values represent means from three $(n=3)$ independent experiments performed in triplicate. 
Table 2

In vitro and in vivo DMPK properties of $\mathbf{8 f}, \mathbf{8 k}, \mathbf{8 m}$ and $\mathbf{8 p}$.

\begin{tabular}{|c|c|c|c|c|}
\hline Property & $8 f$ & $8 \mathbf{k}$ & $8 \mathrm{~m}$ & $8 p$ \\
\hline MW & 398.4 & 407.4 & 407.4 & 407.4 \\
\hline $\operatorname{cLog} \mathrm{P}$ & 2.66 & 2.92 & 2.92 & 2.92 \\
\hline TPSA & 93.4 & 93.8 & 93.8 & 93.8 \\
\hline \multicolumn{5}{|l|}{ In vitro $\mathrm{PK}$ parameters } \\
\hline $\mathbf{C L}_{\mathrm{INT}}(\mathrm{mL} / \mathrm{min} / \mathrm{kg})$, rat & 415 & 57.1 & 81.6 & 134.0 \\
\hline $\mathbf{C L} \mathbf{L}_{\mathrm{HEP}}(\mathrm{mL} / \mathrm{min} / \mathrm{kg})$, rat & 59.9 & 31.5 & 37.7 & 46.0 \\
\hline $\mathbf{C L}_{\mathrm{INT}}(\mathrm{mL} / \mathrm{min} / \mathrm{kg})$, human & 20.1 & 19.6 & 20.2 & 19.2 \\
\hline $\mathbf{C L}_{\mathrm{HEP}}(\mathrm{mL} / \mathrm{min} / \mathrm{kg})$, human & 15.2 & 17.8 & 17.1 & 14.8 \\
\hline Rat fu plasma & 0.037 & 0.002 & 0.004 & 0.002 \\
\hline Human fu plasma & 0.013 & 0.029 & 0.023 & 0.011 \\
\hline Rat fubrain & 0.042 & ND & ND & 0.020 \\
\hline \multicolumn{5}{|l|}{ Cytochrome $\mathrm{P}_{450}\left(\mathrm{IC}_{50}, \mu \mathrm{M}\right)$} \\
\hline $1 \mathrm{~A} 2$ & 9.7 & 2.5 & 0.79 & 11 \\
\hline $2 \mathrm{C} 9$ & 2.3 & 25 & 26 & $>30$ \\
\hline 2D6 & 1.3 & $>30$ & $>30$ & 19 \\
\hline $3 \mathrm{~A} 4$ & 0.34 & 24 & 25 & $>30$ \\
\hline \multicolumn{5}{|c|}{ IV Pharmacokinetics (SD Rat; 0.1-1.0 mg/kg) } \\
\hline $\mathrm{CL}_{\mathrm{p}}(\mathrm{mL} / \mathrm{min} / \mathrm{kg})$ & 9.0 & 3.6 & 1.7 & 1.6 \\
\hline Elimination $\mathrm{t}^{1} / 2(\mathrm{hr})$ & 1.5 & 1.7 & 0.48 & 2.7 \\
\hline $\mathrm{V}_{\mathrm{ss}}(\mathrm{L} / \mathrm{kg})$ & 1.1 & 0.50 & 0.60 & 0.34 \\
\hline \multicolumn{5}{|c|}{ Brain Distribution (0.25 hr) (SD Rat; $0.1-0.2 \mathrm{mg} / \mathrm{kg}$ IV) } \\
\hline $\mathrm{K}_{\mathrm{p} \text {, brain:plasma }}$ & 0.94 & 0.21 & 0.13 & 0.11 \\
\hline $\mathrm{K}_{\mathrm{p}, \mathrm{uu} \text {, brain:plasm }}$ & 1.1 & ND & ND & 1.2 \\
\hline MDCK-MDR1 (Pgp) ER & 1.1 & ND & ND & 1.7 \\
\hline
\end{tabular}

$\mathrm{ND}=$ not determined 